IZA DP No. 737

Unions, Work-Related Training and Wages: Evidence for British Men

\author{
Alison L. Booth \\ Marco Francesconi \\ Gylfi Zoega
}

March 2003 


\title{
Unions, Work-Related Training, and Wages: Evidence for British Men
}

\author{
Alison L. Booth \\ University of Essex, Australian National University \\ and IZA Bonn \\ Marco Francesconi \\ ISER, University of Essex and IZA Bonn \\ Gylfi Zoega \\ Birkbeck College, University of London
}

\author{
Discussion Paper No. 737 \\ March 2003
}

\author{
IZA \\ P.O. Box 7240 \\ D-53072 Bonn \\ Germany \\ Tel.: +49-228-3894-0 \\ Fax: +49-228-3894-210 \\ Email: iza@iza.org
}

\begin{abstract}
This Discussion Paper is issued within the framework of IZA's research area Welfare State and Labor Market. Any opinions expressed here are those of the author(s) and not those of the institute. Research disseminated by IZA may include views on policy, but the institute itself takes no institutional policy positions.
\end{abstract}

The Institute for the Study of Labor (IZA) in Bonn is a local and virtual international research center and a place of communication between science, politics and business. IZA is an independent, nonprofit limited liability company (Gesellschaft mit beschränkter Haftung) supported by the Deutsche Post AG. The center is associated with the University of Bonn and offers a stimulating research environment through its research networks, research support, and visitors and doctoral programs. IZA engages in (i) original and internationally competitive research in all fields of labor economics, (ii) development of policy concepts, and (iii) dissemination of research results and concepts to the interested public. The current research program deals with (1) mobility and flexibility of labor, (2) internationalization of labor markets, (3) welfare state and labor market, (4) labor markets in transition countries, (5) the future of labor, (6) evaluation of labor market policies and projects and (7) general labor economics.

IZA Discussion Papers often represent preliminary work and are circulated to encourage discussion. Citation of such a paper should account for its provisional character. A revised version may be available on the IZA website (www.iza.org) or directly from the author. 


\section{ABSTRACT \\ Unions, Work-Related Training, and Wages: Evidence for British Men*}

Using data from the British Household Panel Survey from 1991 to 1996, the authors investigate the impact of union coverage on work-related training and how the union-training link affects wages and wage growth for a sample of full-time men. Relative to uncovered workers, union-covered men are more likely to receive training and also receive more days of training. In addition, union-covered men experience greater returns to training, and coveredtrained workers face a higher wage growth. While some of these findings have been found in previous studies, others are new. The wage results, in particular, suggest a rethinking is warranted of the conventional view that union wage formation in Britain reduces the incentives to acquire work-related training.

JEL Classification: J24, J31, J41

Keywords: $\quad$ general training, human capital, union coverage, wages

Corresponding author:

Marco Francesconi

ISER

University of Essex

Colchester CO4 3SQ

United Kingdom

Tel.: +44 1206873534

Fax: +441206873151

Email: mfranc@essex.ac.uk

\footnotetext{
* This research was supported by funds from the Leverhulme Trust under Award F/00213C "Workrelated Training and Wages of Union and Non-union Workers in Britain" and from the Economic and Social Research Council. For their helpful comments, we are grateful to Ken Burdett, Ken Chay, Richard Dickens, Gordon Kemp, and seminar participants at the Leverhulme Trust funded joint EssexOxford Workshop at the University of Essex, the Education and Employment Economics Group (EEEG) Workshop at the Department for Education and Employment, the CEPR Labor Economics Workshop at Gerzensee Switzerland, IZA (Bonn), the Australian National University, the London School of Economics, Leicester University and the 1999 EALE Meetings in Regensberg (Belgium). A data appendix with additional results, and copies of the computer programs used to generate the results presented in the paper, are available from Marco Francesconi.
} 


\section{Introduction}

Investments in human capital are central to economic performance and growth. The new growth theory has put them center stage (Lucas 1988; Romer 1990). When tastes and technologies are changing rapidly, such investments (including work-related training) are crucial for keeping labor employed and maintaining high levels of competitiveness. Without a workforce that is continually acquiring new skills, it is difficult to reap all the returns from technological progress.

Against this background, we investigate the impact of union coverage on work-related training and how the union-training link affects wage levels and wage growth for a sample of full-time men in Britain. Our analysis is motivated by recent theoretical developments, which suggest that, contrary to the predictions of standard human capital theory, union-covered workers and firms might face greater incentives to invest in work-related training and that the returns to any such training investment might differ depending on union coverage status. While the nature of the data used in the empirical analysis do not allow us to carry out a clear test of such theories, we are able to see whether or not the standard human-capital-theory predictions are borne out by our data. We therefore aim to establish a number of new stylized facts about the relationship between union recognition and training and their joint impact on wage levels and wage growth.

This is important for policy reasons because, if training and union coverage have both separate and combined effects on workers' performance, policies aimed at stimulating skill formation ought to account for the independent impact generated by the presence of collective bargaining agreements. Similarly, policies that directly affect employment relations and collective bargaining might also need to take into account the impact of training programs on wages. Many countries recognize the link between work-related training and performance by

subsidizing company training or offering support for a training 'market' through loan 
provision and dissemination of information about good practice. Moreover, trade unions are known to affect labor market outcomes, such as productivity, investments, profitability and employment. However the effects of any interplay of unionisation and training on wages and wage growth are not yet fully understood by social researchers or, even partially, embodied within labor market policies. ${ }^{1}$

Previous related studies have focused on the union-training link, on the impact of training on wages, or on the impact of unions on wages. But no study has yet examined the relationship between union coverage and work-related training and how coverage and training jointly affect wage formation and wage dynamics. Such an analysis is obviously complicated by the joint non-random selection of training participants and union workers. In our study, however, the potential endogeneity problem induced by union status is likely to be mitigated by the fact that we are concerned with union coverage rather than membership. The element of individual choice related to coverage is clearly limited in the British context, whereas the decision to become a member of a trade union is possibly determined by constraints, preferences and unobservable factors, which are themselves influenced by membership status. In our empirical analysis, nonetheless, we address the issue of the joint endogeneity of training and coverage when estimating wages, using various econometric techniques and partitioning our sample into subgroups that, in principle, are less likely to suffer from such endogeneity problems.

Our data are from the British Household Panel Survey (BHPS) for the period 19911996. Besides a host of worker and job characteristics, the BHPS provides the only contemporary, longitudinal information on work-related training, union status and individual

\footnotetext{
${ }^{1}$ For example, the 1999 Employment Relations Act in Britain requires employers to provide recognised unions with information and access to discussion on training policies and practices. However, it does not emphasise the relationship of these two institutions and their potential consequences on outcomes such as profitability, workers' morale and job mobility.
} 
wages for a representative sample of workers in Britain. The longitudinal aspect of the BHPS is essential to disentangle at least part of the genuine impact of coverage and training on wages from other spurious effects shared by these three processes.

\section{Conceptual Framework and Related Literature}

The implications of unionism for training and pay depend, inter alia, on the degree of competition in the labor market and on whether the union effect on training is indirect (through the wage structure) or direct (through the negotiation of training). Thus the channels through which union collective bargaining can affect training and pay are potentially quite complex, and it is not immediately obvious that unionism will be associated with positive or negative returns to training. In this section we discuss some of the channels through which unions can affect training and training returns.

\section{Otherwise Competitive Labor Markets}

First, we consider the degree of competition in the labor market. We define as 'otherwise competitive' the situation where the labor market is perfectly competitive except for union presence. The benchmark case is a perfectly competitive labor market without any trade union presence. According to standard human capital theory, in perfectly competitive labor markets - the benchmark case - workers will pay for general work-related training by receiving low training wages, and reap the returns to this investment by receiving higher wages afterwards (Becker 1964). On the other hand, for specific human capital, the requirements of efficient turnover for skilled workers will induce the firm and the worker to agree to share both the costs and the returns of the training investment (Hashimoto 1981).

A necessary condition for efficient training investment in competitive labor markets is that wages are set to facilitate such training investments. In an otherwise competitive labor 
market, union reduction of wage dispersion means that wages cannot be lowered during training and increased after training to allow workers to bear the costs and benefits of general training.

Some studies therefore argue that, where wages are set collectively by trade unions in an otherwise competitive labor market, wage dispersion is reduced and incentives to invest in general training at the workplace are distorted (for example, see Mincer 1983). In particular, workers and firms will not efficiently invest in such training, and there will be a negative correlation between union presence and work-related training (Duncan and Stafford 1980; Barron, Fuess, and Loewenstein 1987). Furthermore, the pay returns to training for unioncovered workers will be lower than the pay returns to training for uncovered workers. These predictions are summarized in the first row of Table 1.

\section{Imperfectly Competitive Labor Markets}

Next, we define an imperfectly competitive labor market as one characterized by some degree of oligopsony, which may arise through search frictions, workers' stochastic preferences for different firms, and the like. In oligopsonistic labor markets, workers receive wages below their marginal product, and thus workers' incentives to invest optimally in general training will be lowered. Some of the returns to training will accrue to the training firms, whose incentives to invest are increased. ${ }^{2}$ Stevens (1996), Acemoglu and Pischke (1999b) and Booth, Francesconi, and Zoega (2002) show conditions under which the wage 'compression' associated with imperfectly competitive labor markets will increase the incentive for firms to finance general or transferable training. ${ }^{3}$ In this context, wage

\footnotetext{
${ }^{2}$ A number of studies (Ryan 1980; Jones 1986; Acemoglu and Pischke 1999a; Leuven and Oosterbeek 1999) show that firms do incur significant financial costs in providing general training.

${ }^{3}$ This model is directed at sectors of the labor market characterized by a production technology requiring skilled labor. Thus oligopsonistic wage compression will be associated with a greater rate of firm-provided training and lower wage growth for skilled workers relative to unskilled workers in the alternative sector whose technology does not require skilled labor.
} 
compression implies that post-training productivity is increasing in training intensity at a faster rate than wages. Hence, the gap between productivity and wages is increasing in training intensity and, by definition, a firm's profits over some range. But the amount of training provided in equilibrium will be sub-optimal from the viewpoint of society.

In imperfectly competitive labor markets, unionism will have ambiguous effects on the pay returns to training. For example, Acemoglu and Pischke (1999b) argue that unions cause wage compression in imperfectly competitive labor markets. In their model, unions set wages and the firm determines training. The model predicts that unionism will be associated with increased firm-financed transferable training. However the pay returns to union-covered workers from such training may be lower if the direct (adverse) effect of unions on wages is stronger than the indirect effect through more training.

In contrast, Booth, Francesconi, and Zoega (2002) model the source of wage compression as workers' stochastic preferences for different firms or heterogeneous mobility costs. In this framework, industry-wide unions bargaining directly over training and wages can extract a share of the surplus and give it to workers in the form of more training and higher wages. Consequently industry-wide unionism will be associated with more transferable training and with higher pay returns from such training. This is because the union is effectively internalizing the friction. ${ }^{4}$ These various predictions are summarized in the second row of Table 1.

\section{Union Concern over the Wage-Employment Package}

Suppose that union utility is increasing in the wages and job security or employment of its members, as is assumed in most models of union behavior. Unions may ensure that

\footnotetext{
4 In another context, Booth and Chatterji (1998) show that union-firm wage bargaining can prevent ex-post monopsonistic wage-setting by firms and can thereby reduce inefficient quits.
} 
covered workers receive higher wages and greater job security by directly intervening in training provision, for example by making sure that workers' skills are deepened and/or kept up-to-date through more training. Thus training is an instrument through which union goals of increasing employment and job security are attained. Consequently, powerful trade unions might be more willing to negotiate better training opportunities for their covered workers, especially in non-competitive product markets in which the available surplus is larger. ${ }^{5}$ Testable predictions from this hypothesis - summarized in Row [3] of Table 1 - are that union-covered firms will provide more training and higher returns for such training, relative to uncovered firms.

\section{Labor Turnover}

It has long been recognized that unions may be instrumental in improving worker morale and organisation at the workplace. This means that, in establishments where unions are recognized, labor turnover may be reduced (Blau and Kahn 1983; Freeman and Medoff 1984). Consequently union-covered firms may have greater incentives to provide training because they are less likely to lose highly productive trained workers (Booth, Francesconi, and Zoega 2002). Through this mechanism, unionism may be associated with increased training and productivity, and consequently wages. ${ }^{6}$ The testable predictions of this hypothesis are that union-covered firms train a greater proportion of their workers and give each worker more training, because covered workers are characterized by lower turnover, ceteris paribus. Thus the training returns for covered workers will be higher than for

\footnotetext{
5 A referee has raised the possibility that a union might comprise heterogeneous membership that is differentiated by skill level. This might have different implications to the model outlined in the text depending on the skill level of the median voter. See Ryan (1994) for further discussion of this approach.

${ }^{6}$ See Booth (1995) for a review of the empirical evidence on unions and productivity for Britain and the United States. Furthermore, analysing a panel of British industries between 1983 and 1996, Dearden, Reed, and Van Reenen (2000) find that higher training is systematically associated with higher productivity.
} 
uncovered workers because of their greater training intensity (holding tenure and all else constant). These predictions are summarized in the fourth row of Table 1.

\section{Unions' Use of Training to Control Labor Supply}

It may be the case that, compared to their uncovered counterparts, union-covered workers hold jobs characterized by an apprenticeship structure, whereby individuals accept lower starting wages for the opportunity to be trained and receive higher post-training wages. Indeed, union organisation in Britain has historically developed on a craft (or occupational) basis, and only later along industrial lines. A traditional strategy of British craft unions was to influence access to training (typically youth access to apprenticeship) as a means of determining labor supply, as well as to monitor the quality of training provided (Webb and Webb 1898; Ryan 1994). To the extent that some elements of this strategy have persisted over time and into the 1990s, we may still observe this channel of influence for specific groups of workers, such as apprentices or young and inexperienced employees. However its predictions for training and training returns are ambiguous. For example, union control over the number of trainees might result in a negative association between unions and training receipt. Trainee numbers might be restricted to increase labor scarcity, thereby lowering incidence but increasing training returns. Conversely, union control over the quality of training might result in a positive association between unions and training incidence and intensity (more and better training per worker to sustain occupational standards) and also for wage growth. These various predictions are summarized in the fifth row of Table 1.

\section{Selectivity and Other Issues}

It is often argued that, in firms that become unionized, management responds to higher union wages by more carefully vetting new hires in order to have a better quality workforce. This implies the selection, by union-covered firms, of higher ability workers and 
perhaps also the boosting of their skills. In addition, from the labor supply side, an implication of some of the theories above is that better quality workers, or more motivated workers, might self-select into unions jobs if the training opportunities and returns are higher in the union-covered sector. For example, if unions bargain directly over training as well as wages, only workers who are able to benefit from such training (that is, those for whom the costs of training are lower) will wish to queue for union jobs, or will be offered such jobs. These predictions are summarized in the last row of Table 1. Notice that they suggest that any observed link between unions, training and training returns may simply be spurious. This emphasizes the need not only to control for potential self-selection into training, but also to control for potential self-selection into union coverage in our empirical analysis. We shall return to this issue below. We would, however, point out that in Britain union coverage is attached to the job and not the individual, and thus the issue of selection is somewhat mitigated.

In many respects, these various hypotheses as to the impact of unionism on training and training returns are observationally equivalent with the data used in our empirical analysis, as inspection of the last column of Table 1 makes clear. Thus the hypotheses summarized in Rows [2.ii], [3], [4] and [5.ii] all have the predictions that union-covered workers will receive more training and higher training returns relative to uncovered workers. On the other hand, the "otherwise competitive' model (see Row [1] of Table 1) is the only hypothesis considered that has the predictions that there will be a negative correlation between union presence and training and that training returns will be lower for union-covered than non-union-covered workers, ceteris paribus.

Furthermore, the hypotheses are not mutually exclusive. For instance, higher job retention of union-covered workers may be at work in imperfectly competitive labor markets. 
Similarly, apprenticeship types of training may go hand in hand with oligopsonistic labor markets. The implications of these hypotheses for the incidence, intensity and pay effects of training may also not be as clear-cut as discussed above. In general, they depend on labor market structure and whether the union effect is direct (through the wage structure) or indirect (through negotiation of training packages). For example, if unions improve worker morale and job organisation and thereby reduce labor turnover, but operate in an imperfectly competitive labor market in which we observe an increasing wage compression (à la Acemoglu-Pischke), then the wage returns to training become lower for covered than uncovered workers. In addition, in this case, the effect of unions on training may be negative if the cost to the firm of training is greater than the benefit of retaining the trained workers, and the rents earned from trained workers fall.

Therefore testing each of the proposed explanations against the others is beyond the scope of this paper and left for future research with richer data. But we can ascertain whether or not the implications of standard human capital theory in otherwise competitive labor markets are borne out by our data. In addition, we aim to explore partially some of the alternative explanations in the attempt of gaining further understanding of the link between training and union coverage, and, especially, as to why any training difference between covered and uncovered workers may exist in Britain during the 1990s.

A number of previous studies using British data have found a positive correlation between work-related training incidence and measures of union presence, such as union coverage for collective bargaining, union recognition or union density (Booth 1991; Greenhalgh and Mavrotas 1992; Arulampalam and Booth 1998; Green, Machin, and Wilkinson 1999). The evidence for the United States draws from a larger body of empirical research and is mixed. Some of the early US studies find a negative impact of unions on training (Duncan and Stafford 1980; Mincer 1983). More recent studies, however, find that 
the probability of receiving on-the-job training and the amount of work-related training received are higher for unionized workers than non-unionized ones (Lynch 1992; Veum 1995; Osterman 1995; Frazis, Herz, and Horrigan, 1995). An exception is the study by Lynch and Black (1998), which uses data from a 1994 representative survey of U.S. establishments and reports no statistically significant impact of unionisation on either the provision of formal training or the proportion of workers receiving it.

To our knowledge, no empirical studies have investigated the wage impact of training received by union-covered workers as compared with uncovered workers. However, the various hypotheses outlined above do have implications for wage levels and wage growth of covered and uncovered trained workers, and our principal aim is to establish some stylized facts in this regard. We shall return to these hypotheses in interpreting our results later in the paper.

\section{The Data}

The data are from the first six waves of the British Household Panel Survey (BHPS), covering the period 1991 to 1996 . The BHPS is a nationally representative random sample survey of private households in Britain. Wave 1 interviews were conducted during the autumn of 1991, and annually thereafter. Our analysis is based on the sub-sample of men born after 1936, who provided complete information at each of the six interview dates, who were in full-time employment at the time of the survey, and who were not self-employed, in the armed forces or farmers. ${ }^{7}$ These restrictions yield a balanced panel of 950 men and 5700 person-year observations. ${ }^{8}$

\footnotetext{
${ }^{7}$ Our analysis is complicated by the potential endogeneity of both coverage and training status to wages. To avoid the additional complicated of self-selection into paid employment, we exclude women from the current study. We plan in future work to investigate these same issues for women.

${ }^{8} \mathrm{We}$ also performed our analyses on an unbalanced panel and found the same broad results as those we reported for the balanced panel. These are available from the authors on request.
} 
Our measure of training incidence takes the value unity if individuals received training, since September 1st of the year preceding the interview, to increase or improve skills in the current job, and zero otherwise. Our measure of training intensity (or duration) is days spent in training to increase or improve skills over the past 12 months in the current job. The Appendix provides the relevant questions and details of the construction of our measures of training incidence, intensity and union coverage. Since the training question explicitly asks for details on "training schemes or courses" that form part of the respondent's present employment, our measure of training is likely to exclude the more informal types of training that occur on-the-job. ${ }^{9}$ Therefore, in interpreting our results, it should be borne in mind that such types of training are not picked up by the BHPS questions, and our estimates will identify the impact of the more formal aspects of work-related training. To the extent that union and non-union workers are equally likely to receive informal training, our estimates will not be affected by this measurement problem. But if, say, non-union employees receive systematically more informal training, we may underestimate the effect of training for these workers. While this is an interesting issue, we cannot investigate it with our data.

The responses to the training questions are given in Table 2, for all person-year observations, disaggregated by trade union coverage. The union coverage variable takes the value of unity for workers covered by a union and zero otherwise. This variable was constructed from the responses to the question about whether or not there is a recognized trade union or staff association for negotiation of pay or work conditions. The potential

\footnotetext{
${ }^{9}$ A potential problem with training data relates to respondents' interpretation of the question. Barron, Berger, and Black (1997) use US data from a matched survey to compare the employer's response about training with the responses of the worker who received the training. They find substantial measurement error in the training variables, and that firms tend to report more training than workers. Campanelli et al. (1994) note, from a study of both linguistic and survey data, that the interpretation of the term "training" varies across groups in the population, in particular employers, employees, and training researchers. They emphasise that individuals in the general population typically interpret training as referring to "that which happens in formal courses" (page 92). This is our focus of interest in the present study, rather than on less formal training that is harder to measure. The potential that informal training is included by some respondents cannot however be ruled out.
} 
endogeneity problem associated with the inclusion of union status in a wages equation is likely to be mitigated by the fact that we are concerned in this paper with union coverage rather than membership. ${ }^{10}$ Approximately $60 \%$ of the sample is covered by union collective bargaining arrangements.

From Column [1] of Table 2 we see that $38.6 \%$ of the sample received training to increase or improve their skills in the current job. Conditional on training receipt, the average number of training days was 4.4. ${ }^{11}$ Columns [2] and [3] give the means for the union-covered and uncovered sub-samples respectively. Training incidence for union-covered men is about 10 percentage points higher than for uncovered men. On average, union-covered men who receive training spend over 2 days more each year in training than do their non-union counterparts. Notice from Column [4] that the difference in training means between the union-covered and uncovered sub-samples is statistically significant at the one-percent level. ${ }^{12}$ There is evidence of some 'recidivism' in training receipt over time. About $60 \%$ of workers who received on-the-job training in any given year $t(t=1991, \ldots, 1994)$ would receive training again in the following year. Notice, however, that the persistence is even larger for

\footnotetext{
${ }^{10}$ The distinction between membership and coverage is important in Britain. This is because closed shops are illegal, and it is therefore possible for workers to be covered by a union for pay (and other job-related aspects of their contract) while "free riding" on membership, thereby avoiding paying the union dues or incurring any costs associated with membership (Booth 1995).

${ }^{11}$ The proportion of workers receiving on-the-job training is fairly stable over 1992-1996, ranging between 36 and $40 \%$ in each wave. The only exception is the first wave of the BHPS in 1991, when $45 \%$ of the respondents in our sample report having received skill-enhancing training. Similarly, the highest number of training days is reported in the 1991 survey (5.9 days on average), the second highest in 1994 (5.4 days) and the lowest in 1996 (3.2 days).

${ }^{12}$ Using data from the 1993 Quarterly Labor Force Survey (QLFS), Green, Machin, and Wilkinson (1999) find that approximately $7 \%$ of manual workers and $17 \%$ of non-manual workers in Britain received formal training in the four weeks that preceded their interview. Using the same data source between 1983 and 1996, Dearden, Reed, and Van Reenen (2000) find that the proportion of workers receiving training during the last four weeks grew from about $5 \%$ to $15 \%$, while the incidence of on-the-job training remained constant over their sample period. It is hard to see how these figures differ from ours, because the definition of training receipt in the QLFS is different (for example, in Green, Machin, and Wilkinson (1999), training receipt is equal to unity if, in the previous four weeks, the worker had taken part in any education or any training connected with the job, or a job that $\mathrm{s} /$ he might be able to do in the future), and the time frame over which training is measured is also different (the last four weeks rather than the last year or so). The incidence of work-related training appears to be lower in Germany between 1986 and 1989 at about 31\% for men aged 16-64 (Pischke 2001), and even lower in the United States for which Lynch (1992) finds that 22\% of white males had some training between 1980 and 1983.
} 
those who did not receive any training in year $t$, having $78 \%$ probability of receiving no training one year later.

Hourly wages are given in the third row of Table $2 .{ }^{13}$ Over the entire sample, workers who received some training earn on average $£ 1.50$ per hour more than workers who did not receive any training at all. This difference is significant at standard statistical levels. Furthermore, hourly wage rates are higher for union than non-union men, and this difference is statistically significant. Consider the pre- and post-training hourly wages for all workers: on average over all men, those who received training have a statistically significant training wage premium of $13.3 \%$. We disaggregate this wage differential to see how it varies across the union and non-union sectors (Columns [2] and [3]). As shown in the last row of Table 2, the pre- and post-training wage differential for union-covered workers is a statistically significant $20.7 \%$, as compared with a statistically insignificant differential of just $4.2 \%$ for non-union covered workers. This is an interesting finding, suggesting that the wage profile is steeper for union-covered men receiving training than for non-union men being trained. Notice also that the pre-training hourly wages of non-union men are $£ 1$ higher than those of union men, a statistically significant difference. However, the post-training wage difference between union and non-union men is not significant, as a result of the large wage gain consequent upon training for union workers.

To provide some preliminary understanding as to why this training premium exists for union-covered men, we stratified the sample by number of years of work experience and number of years of service in the firm. If union-covered jobs were more likely to be

\footnotetext{
13 The hourly wage rate is given as $\omega=\mathrm{PAYGU} /[(30 / 7)(\mathrm{HS}+\kappa \mathrm{HOT})]$, where PAYGU is the usual gross pay per month in the current job (deflated by the 1996 Retail Price Index), HS is standard weekly hours, HOT is paid overtime hours per week, and $\kappa$ is the overtime premium. We set $\kappa$ at 1.5 , the standard overtime rate, but all our results below are robust to alternative values of $\kappa$ ranging between 1 and 2 . Our wage figures are expressed in UK sterling throughout the paper. The average U.S. dollar equivalent (i.e., the exchange rate) of $£ 1$ was $\$ 1.77$ in 1991 and \$1.56 in 1996 (see Office for National Statistics (2000, Table 22.10, p. 398)).
} 
characterized by an apprenticeship type of structure (where individuals accept a lower starting wage for the opportunity to be trained and receive higher post-training wages), then amongst individuals with either modest experience or short firm tenure, wages of union-covered workers may be significantly lower than wages of non-union workers. On the other hand, if unionisation were related to higher job retention, then we would expect to observe greater training receipt and higher wages for union-covered workers than for their non-union counterparts. Among the pool of men receiving training in any of the survey years, there is a significant premium of $£ 0.70-0.80$ in the hourly wage for those who are in union-covered jobs, if their work experience ranges between two and 12 years. For the same group of men, we also observe a significant wage premium of $£ 0.70-1.00$ if they have been with the same firm between one and eight years. We cannot detect any premium or penalty for unioncovered workers with higher or lower experience and tenure levels, nor can we find any union/non-union pay differentials among untrained workers. These results, therefore, do not support the hypothesis that the training measured in our data is the type of training that unioncovered workers are more likely to receive at the beginning of their careers or when they start working for a firm. But the existence of wage premia for more experienced (and with longer firm tenure) union-covered workers is in line with the possibility that unionisation is correlated with higher job retention.

In summary, not only are union-covered men more likely to experience work-related training than uncovered workers, but they also receive larger wage gains consequent upon training. These larger gains are reaped by union-covered workers with relatively long firm tenure and some (but below average) work experience, suggesting that the higher job retention of young experienced union-covered workers is one of the possible mechanisms that explain why union-covered workers have greater returns to training. The raw data therefore provide some evidence that is not consistent with the hypothesis based on otherwise 
competitive labor markets. In the next section, we shall see if this evidence persists after controlling for a large set of explanatory variables. These variables - along with the training, union and wage measures - are defined in Table A1, which also reports their sample means.

\section{Results}

In this section, we report the estimates of a number of models aiming to explore the relationship between union coverage, training and wages. First, using various econometric techniques, we estimate the effect of union coverage on training. Second, we investigate the degree to which the impact of training on wages and wage growth differs across covered and uncovered men. We also present and discuss results from different econometric models that address the issue of the training-coverage endogeneity and the alternative explanations summarized in Table 1 as to why training differences between covered and uncovered workers may exist.

\section{Do Union-covered Men Get More Training?}

We address this question using cross-sectional and panel models of the determinants of training incidence and training intensity for the entire sample of men. Table 3 reports the marginal effects of union coverage, which are calculated as the derivative of the conditional expectation of the observed dependent variable evaluated at the sample means. The marginal effects of all the other variables used in these regressions are not reported for brevity.

The cross-sectional probit estimates reveal that men who are covered by a union are significantly more likely to receive work-related training in the current job. The impact is quite large, with union coverage increasing the training probability by more than 9 percentage points. After controlling for individual-specific unobserved permanent components (e.g., motivation and ability), the fixed-effects logit estimates reveal that the probability of 
receiving job-related training is 5 percentage points higher for union-covered workers than for non-union workers. The tobit estimates show that the presence of labor unions also increases the intensity of work-related training: indeed, men who are covered by a union receive approximately four more days of training than their non-union covered counterparts. This result is robust to the inclusion of unobserved heterogeneity (estimates not shown). In addition, Table 3 reports the results obtained from a censored regression equation, which is estimated using Powell's (1984) censored least absolute deviations (CLAD) estimator. Because the distribution of the intensity variable is highly skewed, this estimator will reflect the central tendency of the data possibly better than the tobit model (Chay and Powell 2001). The results are to be interpreted as the partial effects on the number of days of training conditional on participating in training. The coefficients are qualitatively similar to, though slightly smaller than, those obtained from the corresponding specification of the tobit models. The point estimate implies that, each year, union-covered men who get trained receive about three more days of training than uncovered employees. ${ }^{14}$

Therefore, contrary to the predictions of standard human capital theory, union-covered men are significantly more likely to be trained and receive more days of training than their non-union counterparts, even after accounting for a large set of relevant controls and unobserved heterogeneity. With just this evidence, however, it is hard to see which of the hypotheses discussed above is most appropriate in explaining why this effect emerges. For this purpose, we now investigate whether or not the impact of training on wages differs across union and non-union workers as suggested by the raw data.

\footnotetext{
14 These estimates and the estimates of the other individual and job-related characteristics are broadly consistent with those found in existing studies for Britain (e.g., Arulampalam and Booth 1998; Green, Machin, and Wilkinson 1999) and the United States (e.g., Veum 1995). A discussion of these other estimates can be found in Booth, Francesconi, and Zoega (2002).
} 


\section{Does the Training Effect on Wages Vary with Union Coverage?}

To answer this question, we estimate wage-level and wage-growth equations in order to measure the differential training impact on wages for union and non-union workers. In particular, an individual's hourly wage at time $t, w_{i t}$, can be expressed as

$$
\ln \left(w_{i t}\right)=\alpha U_{i t}+\beta T_{i t}+\gamma\left(T_{i t} \times U_{i t}\right)+\delta Z_{i t}+f_{i}+\varepsilon_{i t},
$$

where $U_{i t}$ is a $0-1$ indicator of whether individual $i$ at time $t$ is in a job covered by a recognized union, $T_{i t}$ is the relevant measure of work-related training (either a dummy variable of training receipt or the number of training days), $Z_{i t}$ is a vector of variables affecting wages that may vary for each individual $i$ over time, the $f_{i}$ s are unobserved characteristics that are individual-specific but time-invariant, and $\varepsilon_{i t}$ is an i.i.d. random shock. The $f_{i}$ s may be correlated with whether workers undergo training or with the likelihood of working in a unionized firm. Thus fitting equation (1) while omitting $f_{i}$ will lead to biased estimates of $\alpha, \beta$, $\gamma$ and $\delta$.

By differencing individuals' wages between year $t$ and year $t$-1, however, all timeinvariant effects (both observed and unobserved) drop out, and the parameters of interest may be estimated without bias. In addition, this first-difference estimation allows us to identify how specific changes in union status are associated with the earnings profile, both on their own and in conjunction with changes in training incidence or training intensity. That is, we separately estimate the effects of entry into, exit from and staying in union-covered jobs on wage growth as well as changes in training (receipt or intensity). This is given by:

$$
\Delta \ln \left(w_{i t}\right)=\sum_{j} \alpha_{j} \Delta U_{i t}^{j}+\sum_{j} \beta_{j} \Delta T_{i t}^{j}+\delta \Delta Z_{i t}+\Delta \varepsilon_{i t}
$$


where $\Delta y_{i t}=y_{i t}-y_{i t-1}$ for any variable $y$ in equation (2), and $j=\operatorname{entry}(e)$, exit $(x)$, stay $(s)$ in a job covered by collective bargaining agreement or offering training, and stay $(0)$ uncovered or untrained. Hence, $\Delta U_{i t}^{e}$ denotes entry into a union-covered job. In the case of the training intensity measure, model (2) will have six possible changes from one interview to the next, that is, being trained the same number of days $\left(\beta_{s}\right)$, moving from untrained to trained $\left(\beta_{e}\right)$, moving from trained to untrained $\left(\beta_{x}\right)$, increase the number of days of training $\left(\beta_{+}\right)$, decrease the number of days of training, but still receiving training $\left(\beta_{-}\right)$, and stay untrained $\left(\beta_{0}\right)$.

Notice that in moving from equation (1) to equation (2), we deliberately left out all the interactions between coverage and training. This is because the computational burden in estimation is thereby reduced, and also because training and union coverage are likely to be jointly endogenous. To address this problem, we then introduce four interaction categories in each year $t$, namely covered-trained $\left(s_{1 t}\right)$, covered-untrained $\left(s_{2 t}\right)$, uncovered-trained $\left(s_{3 t}\right)$, and uncovered-untrained $\left(s_{4 t}\right)$. Changes in these categories are then represented by movements across each particular status between years. This leads to 16 different categories in change form in the case of training receipt and 32 categories in the case of training intensity. The reason for this higher number of change categories is that workers who received some positive number of days of training in a given year may not only receive no training, but also increase, or receive the same or decrease the number of days of training in the following year. For ease of exposition and small sample sizes, however, we combine three of the four possible training intensity transitions (i.e., from trained to untrained, receive the same number of days of training and decrease the number of days of training) into one category and present evidence on 16 transitions only. In this case, the estimated wage growth equation will take the following form 


$$
\Delta \ln \left(w_{i t}\right)=\sum_{j, k} \gamma_{j k}\left(\Delta s_{j, i t} \times \Delta s_{k, i t}\right)+\delta \Delta Z_{i t}+\Delta \varepsilon_{i t}
$$

where $j, k=1, \ldots, 4$, and the parameters $\alpha$ and $\beta$ in (1) are not estimated given our definitions of $s_{j t}$.

\section{Training, Union Coverage, and Wage Levels}

In Table 4 we present pooled ordinary least squares (OLS) and fixed-effects (FE) estimates of the natural logarithm of real (1996 pounds) hourly wage levels. ${ }^{15}$ Table 4 shows the estimates of two different specifications, one that excludes an interaction term of training and union coverage (specification (i)) and another that includes this interaction term (specification (ii)). Panel A contains the estimates obtained with our measure of training incidence, and panel B those obtained with training intensity. Even if the OLS estimates fail to account for the presence of the individual-specific effects, $f_{i}$ in (1), they represent a useful benchmark for comparison purposes, while the FE estimates are consistent. ${ }^{16}$

Workers who are covered by a union receive nearly $4 \%$ higher wages than their nonunion covered counterparts (specification (i) in both training incidence and training intensity FE regressions). We find that this union premium works in conjunction with higher training incidence or intensity (specification (ii)): union-covered workers who receive training earn almost $6 \%$ more than workers who receive training but are not union-covered (i.e., $0.027+0.031$ from the FE estimates, Panel A). Although a higher number of training days

\footnotetext{
${ }^{15}$ The fixed-effects estimates in this table are obtained using a differences-from-means approach. As such, they differ from the other fixed-effects estimates presented below, which have been obtained by estimating equations (2) and (3).

${ }^{16}$ Hausman's specification tests strongly reject the hypothesis that the individual effects are uncorrelated with the right hand side of equation (1), suggesting that random-effects models may be problematic. The estimates for the other explanatory variables listed in the note of Table 4 are omitted because of space limitations, and are available from the authors.
} 
significantly increases covered workers' wages (FE estimates only), this effect is small, with 10 more days of training per year leading to only a $1 \%$ wage increase (Panel B, specification (i)). The wage effect of training intensity, however, disappears in specification (ii), where it is the union-training interaction that becomes significant: 10 additional days of training a year lead union-covered workers to earn 5\% higher wages.

With the goal of distinguishing between some of the explanations outlined earlier, we performed OLS and FE regressions by experience and tenure groups, and found substantial differences across groups. A simpler way to capture this relationship is by introducing an interaction term between training receipt, union coverage and an experience dummy variable (taking value of one if experience is between two and 12 years) and another interaction term between training receipt, union coverage and a tenure dummy variable (taking value of one if tenure is between one and eight years). The FE estimates show that such interaction terms are positive, with an estimated statistically significant wage premium of between 1 and 4\%; this suggests that trained union-covered workers in those experience/tenure brackets do enjoy an extra wage premium. This finding provides some support for the job retention hypothesis.

Notice, however, that, for workers with lower levels of firm tenure (less than one year) and experience (less than two years), there is no statistically significant difference between the pay returns of trained-covered workers and untrained-uncovered workers. This does not seem to be consistent with the hypothesis that training in unionized firms is more likely to follow an apprenticeship type of structure. But it may still be true that (some) unions may use training as a means of controlling quality of young workers, since our data do not contain any information on training quality.

\section{Selectivity checks}

Before turning to the wage growth estimates, we discuss three further exercises that 
investigate the possibility that our results are affected by selectivity problems. To save space, the results from these three exercises are not reported but can be obtained from authors upon request.

First, since participation in training and union coverage are potentially jointly endogenous, we used a two-step procedure to reduce the resulting potential bias. In this instance, the selectivity correction term is obtained by first estimating a bivariate probit model, in which training receipt and union coverage are the dependent variables and the explanatory variables are those used to generate the estimates in Table 3 . The estimated coefficients from this model are then used to construct a selectivity correction term using the method developed by Poirier (1980). The estimates for the training receipt and the union coverage variables are very similar to the OLS estimates reported in Table 4, with the estimated selection term being always statistically insignificant at conventional levels. This suggests that training and coverage are not necessarily jointly endogenous, but it may also mean that the correction term is not suitably identified. ${ }^{17}$ However, Sargan's and other tests (suggested by Bound, Jaeger, and Baker 1995) cannot reject the validity of our instruments at conventional statistical levels.

A second check on the robustness of our results is a test of one of the assumptions of the FE model. Consistency of the FE estimates relies on the assumption that individuals who change coverage-status and training-status are representative of the whole workforce. This may not accord with the idea that nonrandom selection of covered and trained workers is important, which motivated the use of the FE procedure in the first place. Furthermore, if either heteroskedasticity or serial correlation is present in the data, the FE estimates may be

\footnotetext{
${ }^{17}$ Identification has been achieved in our models by including the ratio of unemployment to job vacancies in the local labor market, the industry quit rate, and the interaction between unemployment rate and industry quit rate in the bivariate probit only, and by including tenure and tenure squared in the wage regressions only.
} 
improved upon. These are the reasons why we also estimated a generalized method of moments (GMM) wage model of training and union coverage with additional moment conditions being available from the strict exogeneity assumption (Wooldridge 2001, chapters 10 and 11). This model was estimates on four different samples (i.e., all workers, stayers, quitters, and involuntary job changes) using two specifications (one based on first moments only, and another based on both first-order and second-order conditional moments of wages). The GMM estimates for the entire sample of workers reveal that men who are covered by a collective bargaining agreement receive about $4.5 \%$ higher wages than their uncovered counterparts. As we found earlier, this coverage premium works in association with higher training incidence, with trained covered workers earning 7\% more than trained uncovered workers. A similar picture emerges for the other groups of workers, although the group of 'stayers' faces the highest and the group of 'quitters' the lowest joint gain from coverage and training. The overidentification test statistics for each sample and specification are smaller than their critical values at the 5\% level, indicating that the overidentification restrictions are not inconsistent with the data. However, this is not true in the case of 'quitters' when the GMM estimates are based on both first and second moments. This suggests that changes in coverage and training status are exogenous for stayers and involuntary changers but probably not for quitters.

As noted in Section 2, the issue of selection into union coverage is weakened by the fact that coverage is associated with a job rather than with a worker. But workers with high $f_{i}$ s may have enjoyed careers that were characterized by more training, while better job matches are, ceteris paribus, likely to arise for workers with greater ability and higher propensity to shop for a job (higher search effort). Also, training and union coverage statuses are possibly 
correlated with workers' match quality components. ${ }^{18}$ We exploit the job-coverage link in our data to use the instrumental variable methodology proposed by Altonji and Shakotko (1987), as a third check on the robustness of our results. In addition to individual fixed effects as specified in (1), this methodology allows us to introduce a more complex error structure, which consists of job-match and sector-specific (coverage/non-coverage) effects. ${ }^{19}$ The results from these regressions uphold the findings obtained with the GMM procedure. In particular, the estimates for the subsample of stayers reveal that trained covered workers earn just under $7 \%$ more than trained uncovered workers, while among quitters this premium is only about $4 \%$. Because coverage changes can only occur if unions gain or lose recognition in a firm, these changes are more likely to be exogenous to job-match and individual-specific fixed effects in the case of stayers than in the case of quitters. Thus the estimated returns to training (for covered and uncovered workers) are arguably consistent for the subsample of stayers. Interestingly, the fraction of the residual variance that is attributable to match-specific unobservables is quite large (particularly for quitters, for whom it is about $50 \%$ of the total variance). This indeed may help explain the differences in the returns to training and coverage between stayers and quitters.

The results of Table 4 are therefore confirmed by GMM, selectivity-corrected, and error-component models, at least for all workers but quitters. Although both instrument selection and exogeneity assumptions - which characterize the estimates presented so far are a matter of contention, our results appear to be quite robust and are thus likely to be of

\footnotetext{
${ }^{18}$ One way to provide some correction for this problem in the FE regressions presented above was to add controls for changes in union coverage status as suggested in Loewenstein and Spletzer (1998). We shall follow this procedure below while estimating wage growth regressions.

${ }^{19}$ In this analysis, we treat as endogenous training, coverage, experience and job tenure. All the other variables, which are also used to obtain the estimates reported in Table 4, are treated as exogenous. The instrumental variables used in estimation are given by: (a) the deviations from within-job means of both exogenous and endogenous time-varying variables, and (b) the within-job means of all exogenous variables. For similar applications, see Light and McGarry (1998) and Parent (2000).
} 
general interest.

\section{Training, Union Coverage, and Wage Growth}

In our wage growth analysis, the dependent variable is the change in log wages between two consecutive years, and the independent variables are the year-on-year changes in the workers' characteristics. As discussed above, the differencing procedure eliminates the effect of any omitted-variables bias due to selection into training and coverage, if it is assumed that the selection process varies only across individuals and over time for the same individual (Lynch 1992; Veum 1995). ${ }^{20}$

Table 5 reports the results for the wage growth equations (2) and (3), which differ by whether we use training receipt or training intensity and by the way training and coverage changes are modeled. Notice that, apart from few exceptions, the estimates by equation are remarkably similar regardless of whether we employ training incidence or training intensity.

The results from equation (2) reveal that, compared to workers who remain uncovered in each successive year, those who get a job covered by collective bargaining agreements experience a $6 \%$ higher wage growth $\left(\alpha_{e}\right)$, those who leave a covered job face a $4 \%$ reduction in wage growth $\left(\alpha_{x}\right)$, and those who stay covered do not have any significant wage change $\left(\alpha_{s}\right)$. The same estimates show also that joining a training scheme leads to almost $7 \%$ higher wage growth $\left(\beta_{e}\right)$, while leaving training is associated with about $8 \%$ higher growth $\left(\beta_{e}\right)$. Workers who either increase or decrease the number of hours of training also experience substantial wage growth $\left(\beta_{+}\right.$and $\left.\beta_{-}\right)$. The only workers who do not face any real wage change are those who do not receive any training in two successive years $\left(\beta_{0}\right)$. It is therefore apparent that currently receiving training or having received training sometime in the last year has a

\footnotetext{
${ }^{20}$ With this procedure we cannot identify the effects of the time-invariant characteristics.
} 
positive impact on wage growth

The estimates from equation (3) allow us to assess whether or not union recognition mediates higher returns to training, while dealing with potential endogeneity biases more adequately, as they account for all the possible (annual) transitions in coverage and training status. $^{21}$ The estimates in Table 5 clearly document that gaining coverage is typically associated with a large wage growth (except when workers do not receive training in any two successive years, $\gamma_{42}$ ). For example, uncovered-trained workers who become union-covered enjoy a $2-3 \%$ higher wage growth $\left(\gamma_{31}\right.$ and $\left.\gamma_{32}\right)$. On the other hand, moving from untrained to trained is not associated with steeper wage profiles, unless this change is also accompanied by the acquisition of union coverage or by being always covered ( $\gamma_{41}$ and $\gamma_{21}$, respectively). In this specific instance, however, the training-coverage impact can be quite substantial, up to $6 \%$ higher wage growth.

The table also shows that workers always covered by a union agreement in any given pair of years between 1991 and 1996 experience the highest wage growth, regardless of the measure of training used. This is particularly true in the case of workers leaving training, who benefit from a higher hourly wage growth of about $6-7 \%$ a year $\left(\gamma_{12}\right)$, but it is also true for both stayers as covered-trained $\left(\gamma_{11}\right)$ and stayers as covered-untrained $\left(\gamma_{22}\right)$, who face $5-6 \%$ higher growth. Staying uncovered in any two successive years is associated with lower wage growth, although men who receive training in both years may experience a positive effect. Leaving coverage is associated with flatter or declining wage profiles, especially if workers

\footnotetext{
${ }^{21}$ We also estimated OLS and FE models of hourly wages similar to (1), in which union coverage and training status are not entered as separate variables but are included as covered-trained $\left(s_{1 t}\right)$, covered-untrained $\left(s_{2 t}\right)$, uncovered-trained $\left(s_{3 t}\right)$, and uncovered-untrained ( $s_{4 t}$, base category). The FE estimates show that, relative to the workers in the base category, those who are covered and trained in any year $t\left(s_{1 t}\right)$ receive on average between 5 and $9 \%$ higher hourly wages in that year, those who are covered and untrained $\left(s_{2 t}\right)$ earn $1-3 \%$ higher wages but this premium is never statistically significant, whereas those who are trained and uncovered $\left(s_{3 t}\right)$ receive hourly wages that are $3-4 \%$ significantly lower.
} 
also leave training or are untrained for two consecutive years $\left(\gamma_{23}\right.$ and $\left.\gamma_{24}\right)$. So, as in the estimation of equation (1) where we found that the positive union coverage effect operates together with greater training receipt or duration, the estimates of equation (3) confirm that the combination of training and coverage does have a substantial impact also on wage growth.

To explore the possibility that unions might direct their negotiated training towards younger (in the firm) or less experienced workers, we again partition our sample by work experience and firm tenure, and re-estimate equation (3) by experience-tenure subgroups. The results, not reported for convenience, show that workers with some experience in the labor market (four to twelve years) or workers with longer service in the firm (two to seven years) achieve the highest wage growth - ranging between 6 and $10 \%$ - when they become/stay covered and received/continue to receive training. Instead, workers with less experience or shorter firm tenure benefit of relatively small wage growth effects if they acquire coverage or join a training scheme. Therefore, the wage profiles of experienced (or long-tenured) covered workers appear to be steeper. This finding casts further doubts on the hypothesis that unionized firms tend to organize training in an apprenticeship type of structure (but, again, the possibility that unions use training to control the labor supply and quality of young workers cannot be ruled out with BHPS data). It does however support the hypotheses based on job retention, higher job security and imperfectly competitive labor markets, which cannot be further tested in our data.

Finally, we separately re-estimated equation (3) for three different groups of workers, namely stayers, quitters and workers who involuntarily move to another firm. ${ }^{22}$ This exercise reveals that both stayers and dismissed workers have only a weak positive growth effect if

\footnotetext{
${ }^{22}$ We performed this analysis in the attempt to limit the selection problem caused by the fact that the wage growth effect of acquiring coverage may not be entirely separated from the effect of changing firm (Machin 2000). To increase sample sizes, in this exercise, workers who voluntarily or involuntarily left their firm in any given year between 1991 and 1996 are classified as 'quitters' or 'dismissed workers' over the entire sample period. This implies that these regressions are performed on 2000, 1560 and 1190 observations in the sub-
} 
their current/new firm acquires union recognition, but suffer a strong negative effect on wage growth if they lose union coverage regardless of training status. The opposite results emerge for quitters. On the other hand, training status changes produce wage growth effects similar to those presented earlier for all three groups of workers as long as they are union covered, with the effects for quitters being only slightly higher. Thus, although moving to another firm (either voluntarily or involuntarily) is likely to be correlated with wage growth, the main results of Table 5 do not appear to be affected by the potential endogeneity bias induced by the workers' decision of changing firm.

\section{Conclusions}

In this paper we used data from the British Household Panel Survey for the period 1991-1996 to estimate the impact of trade unions on work-related training and wage formation for a sample of full-time male employees. Our main findings are that, relative to non-union workers, union-covered workers are more likely to receive training, and receive more days of training, than their uncovered counterparts, and also experience greater returns to training and higher wage growth than do trained-uncovered men.

These findings are at odds with the predictions of standard human capital theory that there will be a negative correlation between union presence and training, and that the pay returns to training will be lower for union covered than uncovered workers. Instead, our results are consistent with some of the alternative hypotheses that we outlined earlier in the paper and summarized in Rows [2.ii], [3], [4] and [5.ii] of Table 1. With our data, such explanations are largely observationally equivalent, so it is not possible to discriminate further between them. Nevertheless, several robustness checks and ancillary econometric 
evidence seem to provide little support for the hypothesis based on union workers holding apprenticeship-type of jobs and for that based on selectivity. Conversely, the three remaining explanations - one based on imperfectly competitive labor markets where unions are able to extract some of the surplus associated with the labor market frictions (through higher wages and training), the other based on unions' ability to reduce labor turnover, and the last based on unions' objective to increase job security - appear to be borne out by the BHPS data under analysis. However, our data do not allow us to assess these hypotheses further, and we would require more sophisticated information to be able to test one against the other more formally. In addition, our data cannot suitably identify informal workplace-based training, which may affect non-union workers differently from union workers. Indeed, this could be one reason why, against the predictions of economic theory, we find that the wage returns to training are negligible for uncovered male employees.

While it is well known that in Britain union presence is associated with more workrelated formal training, the positive impact of unions on the wages of trained men has not been noted before. Whether or not this is a peculiarity of Britain, or even of Britain in the 1990 s, remains to be seen. 


\section{APPENDIX}

\section{The data}

\section{Training Incidence}

The precise form of the BHPS training incidence question, asked of all individuals currently in work, is as follows: "Since September 1st last year, have you taken part in any education or training schemes or courses, as part of your present employment?" If yes, the respondent was then asked: "Was any of this training (a) training to help you get started in your current job? (b) to increase your skills in your current job for example by learning new technology? (c) to improve your skills in the current job? (d) to prepare you for a job or jobs you might do in the future? (e) to develop your skills generally?" Our focus of interest in the present paper is on work-related training to improve or increase skills in the current job, rather than induction training or training for future work or for skills generally. For this reason, we use the responses to (b) and (c) of this question to construct our training incidence measure. In addition to the results reported in this paper, however, we also performed the entire analysis with a measure of training incidence defined over the five types of training (a)-(e) listed above. We do not present the results obtained from this alternative measure because they were virtually identical to those reported in this study.

\section{Total Time Spent in Training}

The questions on training incidence were followed by a question on total time spent in all forms of training, as follows: "Since September last year, how long have you spent on this training? Please tell me approximately how much time you have spent on training in total." The units of time requested varied across earlier waves of the BHPS. At Wave 1, individuals were asked to report how many days were spent in training; at Wave 2, how many hours per week and the number of weeks; at Waves 3, 4, 5 and 6 respondents were free to choose the unit of time spent in training. For all waves, we converted responses to this question into days spent in training of type (b) and/or (c) over the past 12 months in the current job. This was hours, days, week or other at Waves 3 and 4, and hours, days, weeks months, or other at Waves 5 and 6 . The cases for which a measure of training intensity could not be consistently computed were dropped. 


\section{Union status}

The precise form of the question about union status is as follows: "Is there a trade union, or a similar body such as a staff association, recognized by your management for negotiating pay or conditions for the people doing your sort of job in your workplace?" While Waves 1, 5 and 6 of the BHPS asked both job-movers and job-stayers for information on union status, the Waves 2-4 questionnaires only requested this if individuals changed employer. In our empirical analysis, we assume that Wave 1 union coverage remains constant across Waves 2, 3 and 4 for people who did not change employer, which is reasonable given that there is evidence that coverage did not alter for people in work over the period. 


\section{References}

Acemoglu, Daron, and Jörn-Steffen Pischke. 1999a. "Beyond Becker: Training in Imperfect Labor Markets.” Economic Journal, F112-F142.

Acemoglu, Daron, and Jörn-Steffen Pischke. 1999b. "The Structure of Wages and Investment in General Training.” Journal of Political Economy, Vol.107, No. 3, pp. 539-72.

Altonji, Joseph G., and Robert A. Shakotko. 1987. "Do Wages Rise with Seniority?" Review of Economic Studies, Vol. 54, pp. 437-59.

Altonji, Joseph G., and James R. Spletzer. 1991. "Worker Characteristics, Job Characteristics, and the Receipt of On-the-Job Training." Industrial and Labor Relations Review, Vol. 45, No. 1, pp. 58-79.

Arulampalam, Wiji, and Alison L. Booth. 1998. "Labor Market Flexibility and Skills Acquisition: Is There a Trade-off?" British Journal of Industrial Relations, Vol. 36, No. 4, pp. 521-36.

Barron, John M., Mark C. Berger, and Dan A. Black. 1997. On-the-Job Training, W.E. Upjohn Institute for Employment Research.

Barron, John M, Fuess, Scott M, Jr, and Mark A Loewenstein. 1987. "Further Analysis of the Effect of Unions on Training (Union Wages, Temporary Layoffs, and Seniority)", Journal of Political Economy, Vol. 95, No. 3, pp. 632-40.

Becker, Gary S. 1964. Human Capital: A Theoretical and Empirical Analysis, with Special Reference to Education. New York: Columbia University Press (for the National Bureau of Economic Research).

Blau, Francine D., and Lawrence M. Kahn. 1983. "Unionism, Seniority, and Turnover." Industrial Relations, Vol. 22, No. 3, pp. 362-73.

Blundell, Richard, Lorraine Dearden, and Costas Meghir. 1996. "The Determinants and Effects of Work related Training in Britain.” London: Institute for Fiscal Studies.

Booth, Alison L. 1991. "Job-related Formal Training: Who Receives It and What Is It Worth?" Oxford Bulletin of Economics and Statistics, Vol. 53, pp. 281-94.

Booth, Alison L. 1995. The Economics of the Trade Union. Cambridge: Cambridge University Press.

Booth, Alison L., and Monojit Chatterji. 1998. "Unions and Efficient Training." Economic Journal, Vol. 108, pp. 328-43.

Booth, Alison L., Marco Francesconi, and Gylfi Zoega. 2002. "Oligopsony, Institutions and the Efficiency of General Training." IZA Discussion Paper No. 618. 
Bound, John, David A. Jaeger, and Regina M. Baker. 1995. "Problems with Instrumental Variables Estimation when the Correlation Between the Instruments and the Endogenous Variable is Weak." Journal of the American Statistical Association, 90, pp. 443-50.

Campanelli, Pamela, and Joanna Channell, with contributions from Liz McAulay, Antoinette Renouf and Roger Thomas. 1994. Training: An Exploration of the Word and the Concept. Employment Department Research Series No. 30, July.

Chay, Kenneth Y., and James L. Powell. 2001. "Semiparametric Censored Regression Models." Journal of Economic Perspectives, Vol. 15, No. 4, pp. 29-42.

Dearden, Lorraine, Howard Reed, and John Van Reenen. 2000. "Who Gains when Workers Train? Training and Corporate Productivity in a Panel of British Industries." Institute for Fiscal Studies Working Paper No. 00/04, March.

Department for Education and Employment. 2001. Opportunity for All in a World of Change. White Paper on Enterprise, Skills and Innovation. London, February.

Duncan, Greg J., and Frank P. Stafford. 1980. "Do Union Members Receive Compensating Differentials?" American Economic Review, Vol. 70, No. 3, pp. 355-71.

Farber, Henry S. 1983. "The Determination of the Union Status of Workers." Econometrica, Vol. 51, No. 5, pp. 1417-38.

Frazis, Harley J., Diane E. Herz, and Michael W. Horrigan. 1995. "Employer-Provided Training: Results from a New Survey.” Monthly Labor Review, May, pp. 3-17.

Freeman, Richard B., and James L. Medoff. 1984. What Do Unions Do? New York: Basic Books.

Green, Francis, Stephen Machin, and David Wilkinson. 1999. "Trade Unions and Training Practices in British Workplaces." Industrial and Labor Relations Review, Vol. 52, No. 2, pp. 179-95.

Greenhalgh, Christine, and George Mavrotas. 1994. "The Role of Career Aspirations and Financial Constraints in Individual Access to Vocational Training." Oxford Economic Papers, Vol. 46, pp. 579-604.

Hashimoto, Masanori. 1981. "Firm-Specific Human Capital as a Shared Investment." American Economic Review, Vol. 71, No. 3, pp. 475-82.

Jones, Ian S. 1986. “Apprentice Training Costs in British Manufacturing Establishments: Some New Evidence.” British Journal of Industrial Relations, Vol. 24, pp. 333-64.

Leuven, Edwin, and Hessel Oosterbeek. 1999. "Demand and Supply of Work-related Training: Evidence from Four Countries." Research in Labor Economics, Vol. 18, pp. 303-30. 
Light, Audrey, and Kathleen McGarry. 1998. "Job Change Patterns and the Wages of Young Men.” Review of Economics and Statistics, Vol. 80, pp. 276-86.

Lowenstein, Mark A., and James R. Spletzer. 1998. "Dividing the Costs and Returns to General Training." Journal of Labor Economics, Vol. 16, No. 1, pp. 142-71.

Lucas, Robert E. Jr. 1988. "On the Mechanics of Economic Development." Journal of Monetary Economics, Vol. 22, pp. 3-42.

Lynch, Lisa M. 1992. "Private Sector Training and the Earnings of Young Workers." American Economic Review, Vol. 81, No. 1, pp. 299-312.

Lynch, Lisa M., and Sandra E. Black. 1998. "Beyond the Incidence of Employer-provided Training." Industrial and Labor Relations Review, Vol. 52, No. 1, pp. 64-81.

Machin, Stephen. 2000. "Union Decline in Britain." British Journal of Industrial Relations, Vol. 38, No. 4, pp. 631-45.

Mincer, Jacob. 1983. "Union Effects: Wages, Turnover, and Job Training." Research in Labor Economics, Supplement 2, pp. 217-52.

Office for National Statistics. 2000. Annual Abstract of Statistics. 2000 edition, No. 136. London: The Stationary Office.

Osterman, Paul. 1995. "Skill, Training, and Work Organization in American Establishments." Industrial Relations, Vol. 34, No. 2, pp. 125-46.

Parent, Daniel. 2000. "Industry-Specific Capital and the Wage Profile: Evidence from the National Longitudinal Survey of Youth and the Panel Survey of Income Dynamics." Journal of Labor Economics, Vol. 18, No. 2, pp. 306-23.

Pischke, Jörn-Steffen 2001. "Continuous Training in Germany." Journal of Population Economics, Vol. 14, No. 3, pp. 523-48.

Poirier, Dale J. 1980. "Partial Observability in Bivariate Probit Models." Journal of Econometrics, Vol. 12, pp. 209-17.

Powell, James L. 1984. "Least Absolute Deviations Estimated for the Censored Regression Model. Journal of Econometrics, Vol. 25, No. 3, pp. 303-25.

Romer, Paul M. 1990. “Endogenous Technological Change.” Journal of Political Economy, Vol. 98, No. 5 (part 2), pp. S71-S102.

Ryan, Paul. 1980. "The Cost of Job Training for a Transferable Skill.” British Journal of Industrial Relations, Vol. 8, pp. 334-52.

Ryan, Paul. 1994. "Training Quality and Training Exploitation", in Richard Layard, Ken Mayhew and Geoffrey Owen (eds.), Britain's Training Deficit, Avebury, pp. 92-124. 
Stevens, Margaret. 1996. "Transferable Training and Poaching Externalities." Chapter 2 in Alison L. Booth and Dennis J. Snower (eds.) Acquiring Skills: Market Failures, their Symptoms and Policy Responses. Cambridge: Cambridge University Press.

Veum, Jonathan. 1995. "Sources of Training and Their Impact on Wages." Industrial and Labor Relations Review, Vol. 48, No. 4, pp. 812-26.

Webb, Sidney, and Beatrice Webb. 1898. Industrial Democracy, London: United Society of Boilermakers and Ironshipbuilderps.

Wooldridge, Jeffrey M. 2001. Econometric Analysis of Cross Section and Panel Data. Cambridge, Mass.: MIT Press. 
Table 1. Testable Predictions of Various Hypotheses

\begin{tabular}{|c|c|c|c|}
\hline & Model & Description & $\begin{array}{c}\text { Empirical Predictions for } \\
\text { Individual-level Data }\end{array}$ \\
\hline [1] & Otherwise competitive & $\begin{array}{l}\text { Unions flatten wage profiles, } \\
\text { reducing wage dispersion and } \\
\text { distorting workers' incentives to } \\
\text { invest in training. }\end{array}$ & $\begin{array}{l}\text { Negative correlation between union } \\
\text { presence and training. Training returns } \\
\text { lower for union-covered than non-union } \\
\text { covered workers. }\end{array}$ \\
\hline \multirow[t]{2}{*}{ [2] } & $\begin{array}{l}\text { Oligopsonistic labor } \\
\text { market }\end{array}$ & $\begin{array}{l}\text { [i] Wage compression associated } \\
\text { with unions means that firms are } \\
\text { more likely to finance training. }\end{array}$ & $\begin{array}{l}\text { Union-covered workers receive sub- } \\
\text { optimal levels of training. Ambiguous } \\
\text { predictions as to the training returns of } \\
\text { union-covered than non-union covered } \\
\text { workers. }\end{array}$ \\
\hline & & $\begin{array}{l}\text { [ii] Unions bargain at industry-level } \\
\text { directly over wages and training. }\end{array}$ & $\begin{array}{l}\text { Union-covered workers receive more } \\
\text { training and higher training returns } \\
\text { relative to uncovered workers. }\end{array}$ \\
\hline [3] & $\begin{array}{l}\text { Union concern over the } \\
\text { wage and employment } \\
\text { package }\end{array}$ & $\begin{array}{l}\text { Unions directly negotiate better } \\
\text { training opportunities for covered } \\
\text { workers, especially in non- } \\
\text { competitive product markets where } \\
\text { the available surplus is larger. }\end{array}$ & $\begin{array}{l}\text { Union-covered workers receive more } \\
\text { training and higher training returns } \\
\text { relative to uncovered workers. }\end{array}$ \\
\hline [4] & Turnover & $\begin{array}{l}\text { Because unions reduce turnover, } \\
\text { they have an indirect effect: union } \\
\text { firms train more workers and each } \\
\text { worker gets more training. }\end{array}$ & $\begin{array}{l}\text { Union-covered workers receive more } \\
\text { training, and also higher training returns } \\
\text { relative to uncovered workers, owing to } \\
\text { their greater training intensity. }\end{array}$ \\
\hline \multirow[t]{2}{*}[5]{} & $\begin{array}{l}\text { Union control over } \\
\text { supply of labor }\end{array}$ & $\begin{array}{l}\text { [i] Control over the number of } \\
\text { trainees reduces the supply of } \\
\text { trained workers, lowering incidence } \\
\text { but increasing returns. }\end{array}$ & $\begin{array}{l}\text { Negative correlation between unions and } \\
\text { training incidence. Training returns for } \\
\text { union-covered workers are greater than } \\
\text { for non-union workers. }\end{array}$ \\
\hline & & $\begin{array}{l}\text { [ii] Control over the quality of } \\
\text { trainees may more and better } \\
\text { training per worker to sustain } \\
\text { occupational standards. }\end{array}$ & $\begin{array}{l}\text { A positive association between unions } \\
\text { and training intensity and also higher } \\
\text { wage growth. }\end{array}$ \\
\hline$[6]$ & Selection models & $\begin{array}{l}\text { Union firms more carefully vet new } \\
\text { hires who are thus on average of } \\
\text { better quality. }\end{array}$ & $\begin{array}{l}\text { More training and greater pay returns for } \\
\text { union-covered workers but this reflects } \\
\text { their higher unobserved ability/quality. } \\
\text { Controlling for unobserved ability } \\
\text { should eliminate this effect. }\end{array}$ \\
\hline
\end{tabular}


Table 2. Training in the Current Job and Wages by Union Coverage, 1991-96

\begin{tabular}{|c|c|c|c|c|}
\hline & $\begin{array}{c}\text { All men } \\
{[1]}\end{array}$ & $\begin{array}{c}\text { Covered } \\
\text { men } \\
{[2]}\end{array}$ & $\begin{array}{c}\text { Uncovered } \\
\text { men } \\
{[3]}\end{array}$ & $\begin{array}{c}\text { Significant } \\
\text { difference } \\
{[4]}\end{array}$ \\
\hline \multicolumn{5}{|l|}{ Training: } \\
\hline Incidence (\%) & 38.56 & 42.46 & 32.72 & $\begin{array}{c}\text { yes } \\
{[0.0000]}\end{array}$ \\
\hline Intensity (days) & 4.41 & 5.25 & 3.16 & $\begin{array}{c}\text { yes } \\
{[0.0000]}\end{array}$ \\
\hline Hourly wages $(£)$ & 8.83 & 8.96 & 8.63 & $\begin{array}{c}\text { yes } \\
{[0.0253]}\end{array}$ \\
\hline Hourly wages if received training $(£)$ & 9.75 & & & \\
\hline Hourly wages if received no training $(£)$ & 8.25 & & & \\
\hline Significant difference & $\begin{array}{c}\text { yes } \\
{[0.0000]}\end{array}$ & & & \\
\hline \multicolumn{5}{|l|}{ Hourly wages for trained workers: } \\
\hline Pre-training wages $(£)$ & 7.94 & 7.50 & 8.57 & $\begin{array}{c}\text { yes } \\
{[0.0088]}\end{array}$ \\
\hline Post-training wages $(£)$ & 9.00 & 9.05 & 8.93 & $\begin{array}{c}\text { no } \\
{[0.7279]}\end{array}$ \\
\hline Training pay gap (\%) & $\begin{array}{l}13.3 \\
{[0.0001]}\end{array}$ & $\begin{array}{l}20.7 \\
{[0.0000]}\end{array}$ & $\begin{array}{c}4.2 \\
{[0.4307]}\end{array}$ & \\
\hline $\mathrm{N}$ & 5700 & 3417 & 2283 & \\
\hline
\end{tabular}

Note: Wages are in constant (1996) prices. The computation of hourly wages is explained in the text. 'Training pay gap' (second row from bottom) is defined as the difference between hourly wages in any wave of data $t$ and the hourly wages of the wave $t-1$, divided by the hourly wages for trained workers in wave $t$ - 1 (expressed in percent). Column [4] (labeled 'Significant difference') reports whether the difference between the figures in columns [2] and [3] are statistically significant [ $p$-values of the $t$-tests for such differences are in square brackets]. $\mathrm{N}$ denotes the number of person-wave observations for our sample of full-time male employees. 
Table 3. The Union-Training Link

\begin{tabular}{cccccc}
\hline & \multicolumn{2}{c}{ Training incidence } & & \multicolumn{2}{c}{ Training intensity } \\
\cline { 2 - 3 } & $\begin{array}{c}\text { Cross-sectional } \\
\text { probit model }\end{array}$ & $\begin{array}{c}\text { Fixed-effects } \\
\text { logit model }\end{array}$ & & $\begin{array}{c}\text { Cross-sectional } \\
\text { tobit model }\end{array}$ & $\begin{array}{c}\text { CLAD } \\
\text { model }\end{array}$ \\
\hline \multirow{3}{*}{ Union coverage } & $0.092^{* * *}$ & $0.052^{* *}$ & & $4.348^{* * * *}$ & $2.987^{* * * *}$ \\
& $(4.288)$ & $(1.987)$ & & $(5.031)$ & $(4.010)$
\end{tabular}

Note: $\mathrm{CLAD}=$ censored least absolute deviations. Figures are marginal effects computed at mean values. The figure in the column labelled CLAD represents the partial effect on intensity conditional on participating in training. All regressions include also the variables listed in Table A1 (in the fixed-effects logit model, the timeinvariant variables are not included). These estimates are not reported, but can be obtained from the authors. Absolute $t$-statistics are in parentheses. In the cross-sectional probit regressions, the $t$-statistics are obtained from Huber-White standard errors. The number of person-wave observations is 5700. The mean of the dependent variable in the training incidence regressions is 0.386 . The mean of the dependent variable in the training intensity regressions is 4.412 .are brackets.

*** significant at 0.01 level, ** significant at 0.05 level. 
Table 4. Log Hourly Wage Estimates

\begin{tabular}{|c|c|c|c|c|}
\hline \multirow[b]{2}{*}{ Variable } & \multicolumn{2}{|c|}{ Ordinary Least Squares } & \multicolumn{2}{|c|}{ Fixed-effects } \\
\hline & (i) & (ii) & (i) & (ii) \\
\hline A. Training incidence & & & & \\
\hline Training & $\begin{array}{l}0.033 * * \\
(2.231)\end{array}$ & $\begin{array}{l}-0.006 \\
(0.260)\end{array}$ & $\begin{array}{c}0.010 \\
(1.428)\end{array}$ & $\begin{array}{l}-0.008 \\
(1.329)\end{array}$ \\
\hline Union coverage & $\begin{array}{l}0.057 * * * \\
(2.674)\end{array}$ & $\begin{array}{l}0.034 * * \\
(2.123)\end{array}$ & $\begin{array}{l}0.039 * * * \\
(3.124)\end{array}$ & $\begin{array}{l}0.027 * * \\
(2.069)\end{array}$ \\
\hline Training $\times$ union & & $\begin{array}{l}0.064^{* *} \\
(2.168)\end{array}$ & & $\begin{array}{l}0.031 \text { *** } \\
(2.633)\end{array}$ \\
\hline $\begin{array}{l}\rho \\
\mathrm{R}^{2}\end{array}$ & 0.468 & 0.469 & $\begin{array}{l}0.753 \\
0.241\end{array}$ & $\begin{array}{l}0.753 \\
0.241\end{array}$ \\
\hline
\end{tabular}

B. Training intensity

$\begin{array}{lcccc}\text { Training } & 0.0001 & -0.001 & 0.001 * * * & 0.0001 \\ & (0.222) & (1.007) & (3.768) & (0.140) \\ \text { Union coverage } & 0.060^{* * *} & 0.055^{* *} & 0.038^{* * *} & 0.039^{* * *} \\ & (2.789) & (2.513) & (3.152) & (3.127) \\ \text { Training } \times \text { union } & & 0.001^{*} & & 0.001 * * \\ & & (1.672) & & (2.064) \\ \rho & & & 0.753 & 0.753 \\ \mathrm{R}^{2} & 0.467 & 0.467 & 0.241 & 0.241\end{array}$

Note: Absolute $t$-statistic are in parentheses (Huber-White standard errors for OLS estimates). Other timevarying controls included in all regressions are: highest educational qualifications (4 dummies), experience, experience squared, tenure, tenure squared, married/cohabiting, living in London, firm size dummies (6), sector (public and charity dummies), occupational dummies (4), whether the worker changed employer in the last 12 months, local unemployment rate and industry quit rate. The OLS regressions also time-invariant controls for occupation of origin (4 dummies) and cohort of entry in the labor market (2). The term $\rho$ is the fraction of variance accounted for by the unobserved heterogeneity component. The number of person-year observations is 5700 .

* significant at 0.10 level, ${ }^{* *}$ significant at 0.05 level, ${ }^{* * *}$ significant at 0.01 level. 
Table 5. Annual Growth of Hourly Wages - Equations (2) and (3)

\begin{tabular}{|c|c|c|c|c|c|}
\hline \multirow[b]{2}{*}{ Variable } & \multirow[b]{2}{*}{ Parameter } & \multicolumn{2}{|c|}{ Training incidence } & \multicolumn{2}{|c|}{ Training intensity } \\
\hline & & Eq. (2) & Eq. (3) & Eq. (2) & Eq. (3) \\
\hline \multicolumn{6}{|l|}{ Union: $^{a}$} \\
\hline Entry & $\alpha_{e}$ & $\begin{array}{l}0.063 * * \\
(2.221)\end{array}$ & & $\begin{array}{l}0.062 * * \\
(2.215)\end{array}$ & \\
\hline Exit & $\alpha_{x}$ & $\begin{array}{l}-0.042 * * \\
(1.984)\end{array}$ & & $\begin{array}{l}-0.042 * * \\
(1.973)\end{array}$ & \\
\hline Stay & $\alpha_{s}$ & $\begin{array}{l}-0.004 \\
(0.379)\end{array}$ & & $\begin{array}{l}-0.005 \\
(0.457)\end{array}$ & \\
\hline \multicolumn{6}{|l|}{ Training: } \\
\hline Entry & $\beta_{e}$ & $\begin{array}{l}0.068^{* * *} \\
(3.352)\end{array}$ & & $\begin{array}{l}0.068 * * * \\
(3.358)\end{array}$ & \\
\hline Exit & $\beta_{x}$ & $\begin{array}{l}0.078^{* * * *} \\
(3.668)\end{array}$ & & $\begin{array}{l}0.079 * * * \\
(3.685)\end{array}$ & \\
\hline Stay trained & $\beta_{s}$ & $\begin{array}{l}0.067 * * * \\
(3.210)\end{array}$ & & $\begin{array}{c}0.042 \\
(1.338)\end{array}$ & \\
\hline Stay untrained & $\beta_{0}$ & $\begin{array}{c}0.007 \\
(0.843)\end{array}$ & & $\begin{array}{l}0.005 \\
(0.502)\end{array}$ & \\
\hline Increase training & $\beta_{+}$ & & & $\begin{array}{l}0.062 * * * \\
(2.858)\end{array}$ & \\
\hline Decrease training & $\beta_{-}$ & & & $\begin{array}{l}0.078^{* * * *} \\
(3.411)\end{array}$ & \\
\hline \multicolumn{6}{|l|}{ Covered-trained to: } \\
\hline Covered-trained & $\gamma_{11}$ & & $\begin{array}{l}0.057 * * * \\
(3.509)\end{array}$ & & $\begin{array}{l}0.051 * * \\
(2.422)\end{array}$ \\
\hline Covered-untrained & $\gamma_{12}$ & & $\begin{array}{l}0.059 * * * \\
(2.843)\end{array}$ & & $\begin{array}{l}0.066^{* * *} \\
(3.248)\end{array}$ \\
\hline Uncovered-trained & $\gamma_{13}$ & & $\begin{array}{l}-0.007 \\
(0.473)\end{array}$ & & $\begin{array}{l}-0.024 \\
(0.331)\end{array}$ \\
\hline Uncovered-untrained & $\gamma_{14}$ & & $\begin{array}{l}-0.008 \\
(1.193)\end{array}$ & & $\begin{array}{l}-0.030 \\
(0.571)\end{array}$ \\
\hline \multicolumn{6}{|l|}{ Covered-untrained to: } \\
\hline Covered-trained & $\gamma_{21}$ & & $\begin{aligned} & 0.024^{*} \\
&(1.763)\end{aligned}$ & & $\begin{array}{l}0.058 * * * \\
(2.718)\end{array}$ \\
\hline Covered-untrained & $\gamma_{22}$ & & $\begin{array}{l}0.052 * * * \\
(3.822)\end{array}$ & & $\begin{array}{l}0.057 * * * \\
(3.269)\end{array}$ \\
\hline Uncovered-trained & $\gamma_{23}$ & & $\begin{array}{l}-0.040 \\
(1.153)\end{array}$ & & $\begin{array}{l}-0.032^{* *} \\
(1.973)\end{array}$ \\
\hline Uncovered-untrained & $\gamma_{24}$ & & $\begin{array}{l}-0.045^{* *} \\
(2.154)\end{array}$ & & $\begin{array}{l}-0.037 \\
(1.528)\end{array}$ \\
\hline $\begin{array}{l}\text { Uncovered-trained to: } \\
\text { Covered-trained }\end{array}$ & $\gamma_{31}$ & & $\begin{array}{l}0.029 * * \\
(2.477)\end{array}$ & & $\begin{array}{l}0.020^{* *} \\
(1.967)\end{array}$ \\
\hline Covered-untrained & $\gamma / 32$ & & $\begin{array}{l}0.033 * * \\
(2.462)\end{array}$ & & $\begin{array}{l}0.031^{* *} \\
(1.984)\end{array}$ \\
\hline Uncovered-trained & $\gamma / 33$ & & $\begin{array}{c}0.040 \\
(1.546)\end{array}$ & & $\begin{array}{l}0.038 * * \\
(2.178)\end{array}$ \\
\hline
\end{tabular}


Uncovered-untrained

$\gamma_{34}$

(1.865)

Uncovered-untrained to:

Covered-trained

Covered-untrained

Uncovered-trained

Uncovered-untrained $\gamma_{41}$

$0.040^{*}$

(1.780)

0.002

$(0.053)$

$-0.031$

(1.388)

$\gamma_{44}$
$0.038^{*}$

0.041

$0.054 * * *$

(2.801)

0.028

$(0.720)$

$-0.026$

$(1.277)$

$-0.043 * * *$

(3.256)

(2.784)

0.067

$\begin{array}{lllll}\mathrm{R}^{2} & 0.063 & 0.064 & 0.063 & 0.067\end{array}$

Note: Absolute $t$-statistic in parentheses (Huber-White standard errors).All regressions are performed on 4750 transitions. Other controls included in all regressions but not reported in the table are yearly changes: in highest educational qualification, tenure and tenure squared, marital status, residential location, firm size, current occupation, sector, employer, two-digit industry quit rate, and local unemployment rate.

${ }^{\mathrm{a}}$ Stay uncovered is the base category.

* significant at 0.10 level, ** significant at 0.05 level, *** significant at 0.01 level. 


\begin{tabular}{|c|c|c|}
\hline Variable & Definition & Mean \\
\hline \multicolumn{3}{|l|}{ Union and training: } \\
\hline Union coverage & $\begin{array}{l}\text { Recognized trade union or similar organisation for negotiating pay and } \\
\text { other similar conditions in the workplace }\end{array}$ & 0.599 \\
\hline Training incidence & $\begin{array}{l}\text { Any training meant to increase or improve skills in the current job over } \\
\text { the previous } 12 \text { months }\end{array}$ & 0.386 \\
\hline Training intensity (days) & $\begin{array}{l}\text { Number of days spent in skill-enhancing training in the past } 12 \text { months } \\
\text { in the current job }\end{array}$ & 4.412 \\
\hline \multicolumn{3}{|l|}{$\begin{array}{l}\text { Individual and labor market } \\
\text { characteristics: }\end{array}$} \\
\hline$\overline{\text { Age }}$ & Age (years) & 38.093 \\
\hline Partner present & Married or cohabiting at interview date & 0.787 \\
\hline Experience & Experience (years) in employment since labor market entry & 19.971 \\
\hline Tenure & Firm tenure (years) in current job & 6.657 \\
\hline Disabled & Registered as disabled either with social services or a green card & 0.009 \\
\hline Changed job & $\begin{array}{l}\text { Changed employer in the previous } 12 \text { months (either though a quit or } \\
\text { after a layoff) }\end{array}$ & 0.126 \\
\hline London & Resident in Greater London & 0.093 \\
\hline No qualification (base) & No educational qualification & 0.209 \\
\hline O-level & $\begin{array}{l}\text { Highest qualification is one or more 'Ordinary'-level qualifications } \\
\text { (later replaced by GCSE), usually taken at the end of compulsory } \\
\text { schooling at age } 16\end{array}$ & 0.323 \\
\hline A-level & $\begin{array}{l}\text { Highest qualification is one or more 'Advanced'-level qualifications, } \\
\text { representing university entrance-level qualification typically taken at } \\
\text { age } 18\end{array}$ & 0.234 \\
\hline Vocational & HND, HNC, Teaching, other higher qualification, Nursing & 0.086 \\
\hline Degree qualification & University degree or above & 0.149 \\
\hline Professional $^{\mathrm{a}}$ & Professional occupations & 0.116 \\
\hline Managerial $^{\mathrm{a}}$ & Managerial occupation & 0.195 \\
\hline Non-manual $^{\mathrm{a}}$ & Skilled non-manual occupation & 0.199 \\
\hline Skilled manual $^{\mathrm{a}}$ & Skilled manual occupation & 0.291 \\
\hline Other manual (base) $)^{\mathrm{a}}$ & Semi-skilled and unskilled manual occupations & 0.199 \\
\hline \multicolumn{3}{|l|}{ Date of labor market entry: } \\
\hline Cohort 1 (base) & Entered the labor market before 1961 & 0.098 \\
\hline Cohort 2 & Entered the labor market $1961-1970$ & 0.268 \\
\hline Cohort 3 & Entered the labor market $1971-1980$ & 0.385 \\
\hline Cohort 4 & Entered the labor market $1981-1990$ & 0.248 \\
\hline \multicolumn{3}{|l|}{ Firm size: } \\
\hline Size25 (base) & Fewer than 25 employees at the establishment & 0.236 \\
\hline Size50 & 25-49 employees at the establishment & 0.123 \\
\hline Size 100 & 50-99 employees at the establishment & 0.141 \\
\hline Size200 & 100-199 employees at the establishment & 0.125 \\
\hline Size 500 & 200-499 employees at the establishment & 0.164 \\
\hline Size1000 & 500-999 employees at the establishment & 0.100 \\
\hline Size $1000+$ & $1000+$ employees at the establishment & 0.111 \\
\hline Public sector & Works in public sector & 0.274 \\
\hline Charity & Works in non-profit making organisation (charities, co-operatives etc.) & 0.019 \\
\hline \multicolumn{3}{|l|}{ Other variables: } \\
\hline Unemployment rate & $\begin{array}{l}\text { Local unemployment rate. The geographic unit is } 306 \text { matched job } \\
\text { centers. Obtained from the National On-line Manpower Information } \\
\text { Service. }\end{array}$ & 0.083 \\
\hline Industry quit rate & $\begin{array}{l}\text { Average quit rate for the two-digit Standard Industrial Classification } \\
\text { (SIC) }\end{array}$ & 0.074 \\
\hline
\end{tabular}




\section{IZA Discussion Papers}

\begin{tabular}{|c|c|c|c|c|}
\hline No. & Author(s) & Title & Area & Date \\
\hline 722 & $\begin{array}{l}\text { C. K. Spiess } \\
\text { F. Büchel } \\
\text { G. G. Wagner }\end{array}$ & $\begin{array}{l}\text { Children's School Placement in Germany: Does } \\
\text { Kindergarten Attendance Matter? }\end{array}$ & 6 & $02 / 03$ \\
\hline 723 & $\begin{array}{l}\text { M. Coles } \\
\text { B. Petrongolo }\end{array}$ & $\begin{array}{l}\text { A Test between Unemployment Theories Using } \\
\text { Matching Data }\end{array}$ & 3 & $02 / 03$ \\
\hline 724 & $\begin{array}{l}\text { J. T. Addison } \\
\text { R. Bailey } \\
\text { W. S. Siebert }\end{array}$ & $\begin{array}{l}\text { The Impact of Deunionisation on Earnings } \\
\text { Dispersion Revisited }\end{array}$ & 2 & $02 / 03$ \\
\hline 725 & S. Habermalz & An Examination of Sheepskin Effects Over Time & 1 & $02 / 03$ \\
\hline 726 & S. Habermalz & $\begin{array}{l}\text { Job Matching and the Returns to Educational } \\
\text { Signals }\end{array}$ & 1 & $02 / 03$ \\
\hline 727 & $\begin{array}{l}\text { M. Raiser } \\
\text { M. Schaffer } \\
\text { J. Schuchardt }\end{array}$ & Benchmarking Structural Change in Transition & 4 & $02 / 03$ \\
\hline 728 & $\begin{array}{l}\text { M. Lechner } \\
\text { J. A. Smith }\end{array}$ & What is the Value Added by Caseworkers? & 6 & $02 / 03$ \\
\hline 729 & $\begin{array}{l}\text { A. Voicu } \\
\text { H. Buddelmeyer }\end{array}$ & $\begin{array}{l}\text { Children and Women's Participation Dynamics: } \\
\text { Transitory and Long-Term Effects }\end{array}$ & 3 & $02 / 03$ \\
\hline 730 & $\begin{array}{l}\text { M. Piva } \\
\text { M. Vivarelli }\end{array}$ & $\begin{array}{l}\text { Innovation and Employment: Evidence from } \\
\text { Italian Microdata }\end{array}$ & 2 & $02 / 03$ \\
\hline 731 & $\begin{array}{l}\text { B. R. Chiswick } \\
\text { N. DebBurman }\end{array}$ & $\begin{array}{l}\text { Educational Attainment: Analysis by Immigrant } \\
\text { Generation }\end{array}$ & 1 & $02 / 03$ \\
\hline 732 & $\begin{array}{l}\text { A. Falk } \\
\text { A. Ichino }\end{array}$ & Clean Evidence on Peer Pressure & 5 & $03 / 03$ \\
\hline 733 & $\begin{array}{l}\text { S. Wolter } \\
\text { S. Denzler }\end{array}$ & $\begin{array}{l}\text { Wage Elasticity of the Teacher Supply in } \\
\text { Switzerland }\end{array}$ & 2 & $03 / 03$ \\
\hline 734 & S. Wolter & Sibling Rivalry: A Six Country Comparison & 2 & 03/03 \\
\hline 735 & $\begin{array}{l}\text { R. Desmet } \\
\text { A. Jousten } \\
\text { S. Perelman } \\
\text { P. Pestieau }\end{array}$ & $\begin{array}{l}\text { Micro-Simulation of Social Security Reforms in } \\
\text { Belgium }\end{array}$ & 3 & $03 / 03$ \\
\hline 736 & $\begin{array}{l}\text { I. Bolvig } \\
\text { P. Jensen } \\
\text { M. Rosholm }\end{array}$ & The Employment Effects of Active Social Policy & 6 & $03 / 03$ \\
\hline 737 & $\begin{array}{l}\text { A. L. Booth } \\
\text { M. Francesconi } \\
\text { G. Zoega }\end{array}$ & $\begin{array}{l}\text { Unions, Work-Related Training, and Wages: } \\
\text { Evidence for British Men }\end{array}$ & 3 & $03 / 03$ \\
\hline
\end{tabular}

An updated list of IZA Discussion Papers is available on the center's homepage www.iza.org. 